\title{
Efectiveness of the Implementation of SIP Sakato and Sakato Sign Applications in Licensing and Non- Licensing Services in West Sumatra Province (Case Study: Investment Service and One-Stop Integrated Services (DPMPTSP) West Sumatra Province)
}

\author{
Aswandi ${ }^{1}$, Afriva Khaidir ${ }^{2}$ \\ \{nestick07@gmail.com ${ }^{1}$, afrivak@yahoo.com² ${ }^{2}$.

\begin{abstract}
Magister Public Administration of Universitas Negeri Padang, Jl. Prof. Dr. Hamka, Air Tawar Barat, Padang ${ }^{1}$,

Magister Public Administration of Universitas Negeri Padang, Jl. Prof. Dr. Hamka, Air Tawar Barat, Padang $^{2}$
\end{abstract}

\begin{abstract}
This research started with various problems in the implementation of SIP Sakato and Sakato Sign applications in online licensing services. Which is licensing services are still done manually, lack of public skills to use the application, overdue on licensing completion, and lack of supporting facilities and infrastructure. This research is qualitative with descriptive methods. The informants were determined using purposive sampling and incidental sampling methods. Data collection was done by interviewing, observing, studying documentation, and testing the validity of the data by using the source triangulation method. Measurement of effectiveness is based on the evaluation elements developed by Daniel Stufflebeam, that is Context, Input, Process, and Product. The results are the implementation of Sakato Sign already good, but no with SIP Sakato application. Because SIP Sakato still needs to be developed, inadequate budget, inadequate internet networks, deficient field survey officers, and delay in submitting technical studies by the Technical Service.
\end{abstract}

Keywords: Efectiveness, E-Government, SIP Sakato, Sakato Sign, Public Services.

\section{Introduction}

The West Sumatra Provincial Government in implementing Bureaucratic Reform by following the mandate of Law Number 25 of 2009 about Public Services continues to strive to improve performance and reform public services, especially licensing services that are under the authority of the provincial government. All aspects of apparatus empowerment, both institutions, apparatus human resources, management, accountability, and directed observation to improving the quality of public services.

West Sumatra Province DPMPTSP is a government agency that is authorized to carry out and sign permits and non-permits, which contained in West Sumatra Governor Regulation 
Number 2 of 2017 concerning Implementation of One-Stop Services for West Sumatra Province as amended by Governor Regulation Number 15 of 2017 and Governor Decree West Sumatra Number 570-54-2017 concerning Delegation of Authority for Service Delivery and Signing of Licensing and Non-Licensing Types as amended by Governor Decree Number 570-422-2017; As for the vision and mission of implementing one-stop integrated services in Governor Regulation Number 2 of 2017, namely "The Realization of Excellent One-Stop Integrated Services in the Framework of Creating a Conducive Investment Climate"

To achieve the vision and mission and as a relator of the licensing service mechanism, a Governor Decree on Standard Operating Procedures (SOP) for licensing services and licensing service standards mandated to issue 247 permits and non-licensing types consisting of 19 sectors. The purpose of establishing SOPs is to realize licensing and non-licensing services that are fast, effective, efficient, transparent, and provide legal certainty, as well as realize the rights of the community and investors to obtain licensing and non-licensing services. Meanwhile, the objective of implementing One-Stop Services is the realization of licensing and non-licensing services that are fast, effective, transparent, and provide legal certainty.

West Sumatra Province DPMPTSP continues to make improvements to increase community satisfaction in enjoying services from the government. Various forms of licensing services are currently carried out at one door only with various conveniences second in terms of requirements, processes, and permit completion time. In licensing services, the government implements E-Government that is the use of information technology tools to facilitate work and improve service quality to achieve effectiveness in implementing the licensing service process. So with this E-Government, it is hoped that licensing services can simplify the community and service providers achieving predetermined goals.

Currently, DPMPTSP West Sumatra Province is providing licensing and non-licensing services to the public that can be done online by using the Electronic Licensing Service Application that is named Sakato Licensing Information System, abbreviated as SIP Sakato. This application provides online services for registration, tracking permits, reporting complaints, and there is also a GIS (Geographic Information System) feature where the public can check the location of license spatially. The presence of the SIP Sakato online licensing service is one of the steps taken by the government to realize the ease of service to the community and shortening the time for processing license from the application stage to the publishing stage of the licensing. All these simply cannot be separated from the desire that the public service sector continues to improve to increase public satisfaction in all aspects of service.

In West Sumatra Province DPMPTSP many obstacles occur, there is a slow process of completing license, inadequate supporting facilities, and infrastructure, and the limited number of employees in providing services, which only 11 Civil Servants Civilians and 6 Contractors in serving 19 sectors and 247 types of permits. Also besides, the length of time that the technical service issues technical recommendations are also one of the factors that cause the completion of the licensing process to not comply with the stipulated SOP. There is the reason why the achievement of SOP objectives in terms of time certainty is still not as expected. The inability to implement SOP provisions results in a low quality of licensing services. Another problem is the lack of ability of the community (applicants) in using the SIP Sakato application in licensing services, and there are still some services that are carried out manually in the application of this online-based Sakato SIP application. So, the licensing service that uses online-based Sakato SIP is also deemed ineffective.

Apart from SIP Sakato, West Sumatra Province DPMPTSP has also implemented an electronic signature system or commonly known as Sakato Sign. This application is one of the government's efforts to provide a sense of security by guaranteeing the authenticity and legality 
of license and non-licensing documents through an authentication system called a digital signature which is part of an electronic signature and in collaboration with the State Crypto Agency (LEMSANEG) and the Communication Office and Informatics of West Sumatra Province. By following the provisions of Law Number 11 of 2008 concerning Electronic Information and Transactions, article 11 states that electronic signatures have legal force and legal consequences, meaning that the rightful power of an electronic signature is the same as a wet signature. This application helps to accelerate the process of implementing licensing and non-licensing services, especially the signing of published documents.

Based on these problems, it is necessary to evaluate the application of the SIP Sakato and Sakato Sign applications in-licensing and non-licensing services at DPMPTSP West Sumatra Province. evaluation explicitly refers to the achievement of goals, while implicit evaluation must compare what has reached from the program with what should be achieved based on predetermined standards [1]. In the program implementation, the criteria in the mean are criteria for the success of the implementation and the things that are rated are the results of the process itself in the framework of decision making. Evaluation can use to check the level of program success about to with concerning the program environment with a "judgment" whether the program is continued, postponed, improved, developed, accepted, or rejected. This evaluation brought to determine whether the stated objectives have reached, provide input on program improvement, supporting factors, an inhibiting factor, and measuring the level of effectiveness of application implementation.

The evaluation theory used is the CIPP (Context, Input, Process, Product) evaluation theory model developed by Daniel Stufflebeam, evaluation as the process of describing, obtaining, and providing useful information to assess alternatives decision making. The CIPP model rests on the view that the urgent objective of program evaluation is not to prove but to improve. Therefore, this model is also category as evaluation-oriented improvements or evaluation for development. The CIPP model has four continuous elements, that are:

1) Context evaluation that identifies and assesses the needs that underlie the development of a program

2) This input evaluation identifies and issues, assets, and opportunities to help decisionmakers define objectives, priorities and contribute the broader group to assess the purpose, primary, benefits of the program, rate alternative approaches, action plans, staff plans, scheduling work, rate activity plans, and budgeting

3) Process evaluation checks the implementation of a predetermined program. This evaluation seeks to rate the practice of the program to help program staff carry out activities and then to help a broader group of users to assess the program and interpret benefits. Process evaluation can review previous program plans and identify important aspects of the program that should control.

4) Product evaluation aims to measure, interpret, and assess program achievements. This evaluation seeks to identify and access outputs and benefits, both planned and unplanned, both short and long term. Both are to help staff keep efforts focused on achieving significant benefits and ultimately to help broader user groups measure the success of the means of reach targeted needs [2].

From the results of the evaluation carried out, it will analyze the effectiveness level of the application of the SIP Sakato and Sakato Sign applications in-licensing and non-licensing services. Effectiveness determines as the level or degree of achievement of the expected results, the greater it is results that can be reach means more effective it is [3]. Effectivity will relate to the basis and objectives of application, development, quality, product, and satisfaction obtained 
by the community in-licensing and non-licensing services through the SIP Sakato and Sakato Sign applications. The effectiveness analysis carried out is the purpose of determining the extent to which the use of the SIP Sakato and Sakato Sign applications can achieve the goals set by DPMPTSP of West Sumatra Province.

The evaluation that is carried out starts from identifying the needs that become the basis for using the application, identifying problems and opportunities in assessing objectives, priorities, program benefits, alternative approaches, program plans, and budgeting. After that, continue to check the implementation of the purpose that has been assign. Finally, measure and achieve the results of the implemented program. From the results of these measurements, if the results obtained are not optimal, the next steps will be formulated to be able to improve and optimize the achievement of the purpose that regulate.

\section{Methodology}

This research uses qualitative descriptive methods. The research was done at the Office of Investment and One-Stop Services, West Sumatra Province. The selection of informants in this study was carried out using a purposive sampling technique to obtain maximum and valid data, and using incidental sampling techniques who happened to meet the community at the research location and had received licensing and non-licensing services from the apparatus. The data used are primary data that comes from interviews and direct observation, and secondary data obtained from documentation studies of literature that can support research.

Data collection techniques are done in order so that researchers get data by following predetermined standards through interviews, observation, and documentation study. To obtain reliable, accurate, and valid data, researchers tested the validity of the data using source triangulation techniques, which are comparing and checking back the degree of confidence of information obtained through different people (sources) until data saturation is achieved [4]. The data analysis process starts with data collection, data reduction, data presentation, and finally concluding.

\section{$3 \quad$ Finding and Discussion}

The purpose of the One-Stop Integrated Service is fast, effective, efficient, transparent, and provide legal certainty, as well as realizing the rights of the public and investors to obtain licensing and non-licensing services. Then DPMPTSP created several programs to achieve these goals, one of which was the use of the SIP Sakato and Sakato Sign applications. SIP Sakato is a licensing information system application that will assist the public in the process of submitting a permit application and assist officials in processing applications for community license created it easier, faster, transparent, effective, and efficient. Meanwhile, Sakato Sign is an application that functions as electronic ratification and signing of licensing and non-licensing documents using a barcode that is carried out by the Head of the Service and in collaboration with the State Crypto Agency in maintaining the legality and authenticity of these documents.

The theory used in evaluating the SIP Sakato and Sakato Sign applications is a theory developed by Daniel Stufflebeam (1966), namely evaluation with the CIPP model what has four continuous elements, that is context evaluation, input evaluation, process evaluation, and product evaluation. 
a. Evaluation Context

The implementat ion of One-Stop Services is an effort to realize licensing and non-licensing services that are fast, effective, efficient, transparent, and provide legal certainty, as well as realize the rights of the public and investors to obtain licensing and non-licensing services. Based on the public services principle in Law Number 25 of 2009 about Public Services, says that implementation of public services is based on legal certainty equality of rights, rights balance, and obligations, professionalism, participation, non-discrimination, openness, accountability, speed, comfort, and affordability. By following Presidential Instruction No. 3 of 2003 about National Policy and Strategy for E-Government Development, it stated that the government seeks to develop (using) electronic-based governance to improve the quality of public services effectively and efficiently. As an embodiment, The West Sumatra Provincial Government uses the SIP Sakato application as regulated in Governor Rule Number 2 of 2017 about the Implementation of One-Stop Services, says that in licensing services, use of the SIP Sakato application as an effort to realize the provision of service processes which is fast, easy, cheap, transparent, certainly, affordable, give protection and legal certainty to the public.

Besides, in terms of developing electronic-based government administration and the realization of a fast, definite service process, providing protection and legal certainty, the West Sumatra Provincial Government in the One-Stop Investment and Integrated Services Office also implements the Sakato Sign. Is by following the provisions of Law Number 11 years 2008 article 11 who states that electronic signatures have legal force and legal consequences, meaning that the law power of an electronic signature is the same as a wet signature.

Each organization has its principles as the foundation upon which the organization. OneStop Integrated Service of West Sumatra Province through the Decree of the Governor of West Sumatra Number: 570 - 500 - 2017 Concerning Service Standards in the Field of Licensing and Non-Licensing Services at the Office of Investment and One-Stop Services of West Sumatra Province, it is stated that in carrying out tasks, it is mandatory to implement the principle of "coordination, integration, synchronization, and simplification."

In the context of realizing Good Governance in One-Stop Integrated Services, the West Sumatra Provincial Government issued Standard Operating Procedures (SOP) contained in the Decree of the Governor of West Sumatra Number: 570-498-2017 concerning Standard Operating Procedures in the Field of Providing Licensing and Non-Licensing Services at the Planting Service Capital and One-Stop Services, West Sumatra Province. Standard Operating Procedure (SOP) applies as a reference by officers who administer the One-Stop Integrated Service at the Investment Service and One Stop Services of West Sumatra Province in providing services to the community. That done as an effort to provide excellent service to the community, so public rights can be fil in maximally services and improve the quality of community services.

In the licensing and non-licensing services provided by DPMPTSP, there are still several problems that occur, including the delay in completing community permit applications from the stipulated SOP. It happened because of multiple examinations of applications submitted by the public, starting from checks by the back office, Section Heads, Heads of Fields, Technical Services concerned with related sectors, and Heads of Services. Other than, the limited number of personnel in providing services is also a factor in delays in completing the license.

The use of the SIP Sakato application provides benefits for the community and service providers. For the community, it can save costs, time, and energy to apply the license that can be done anytime and anywhere without visiting the DPMPTSP office, even that the public can apply for permits on holidayss. Besides, the public can also monitor the extent to which their permit application process is running. For the licensing service administering apparatus, it can accelerate and facilitate the completion of the community permit application process as well as 
an alternative form of overcoming the shortage of service provider staff to save energy and costs.

The application of the Sakato Sign application also has benefits for the community and the government, especially the Head of the Office. The busyness of the Head of Office that often attends meetings outside the office and travels outside the region is one of the factors that slow down the process of completing permit and non-licensing applications due to delays in signing documents to be issued. So that with this Sakato Sign, the Head of Office can still sign documents anytime and anywhere so that it can speed up the process of providing licensing and non-licensing services to the public.

b. Input Evaluation

Input evaluation reaches out to identify and assess system capabilities, program strategy alternatives, and program implementation budgets [5]. It means done to see and rate how ready the organization is in running or implementing a program to achieve the stated goals. Input evaluation takes by starting to analyze the needs in program implementation such as budget availability, provision of facilities and infrastructure, outreach to related parties outside the organization, strategies undertaken to smooth the course of program implementation, and planned activities.

In implementing a program, it is necessary to disseminate information to parties outside the organization related to the program. This socialization reaches to introduce the SIP Sakato and Sakato Sign applications to all people of West Sumatra, especially business actors for the smooth running of this program. DPMPTSP disseminates the application in several ways. The first is by the manual the way, where DPMPTSP gathers government officials from the provincial and area/city levels include technical offices and business actors and business associations/associations throughout West Sumatra. The socialization does by explaining the benefit of using this application and explaining the steps in using this application.

Subsequently, socialization is reached by placing banners in city/regency centers and through information via radios throughout West Sumatra. Also done online, where the official website and social media accounts of the government and all officials will introduce this application to the public. Based on the results of interviews and observations conducted by researchers, at the socialization stage, the DPMPTSP of West Sumatra Province has been reached well and as much as possible.

In using the SIP Sakato application, the development is required to improve the application. The Head of Dinas said that there be improvements to the GIS-based application. However, the perfection that will be doing cannot yet reach due to an inadequate budget. Besides, the availability of a good internet network is also deficient, even if there are already two internet networks, namely the LAN network and the wifi.id network provided by the Communication and Information Office, the internet network is still slow because the speed of the LAN network is only $3 \mathrm{Mbps}$ and the wifi.id network is also unstable. There are two challenges in implementing E-Government, first is the tangible challenge that is a challenge to the limited physical facilities and infrastructure of telecommunications networks and electricity. The second is the intangible challenge, which is a challenge to finance/budget and limited human resources [6].

So that the readiness of DPMPTSP in using the SIP Sakato and Sakato Sign applications on the budget and internet network is still inadequate, for the forwardness of facilities and infrastructure, in terms of computer equipment and the ability of the apparatus to use technological tools, it looks decent and adequate. The electricity is also supported because there is diesel power that will be used when there is a power cut during office operating hours. 
In the use of this application, West Sumatra Province DPMPTSP will always develop the application gradually as an effort to improve the application to provide excellent service to the community. For application development to reach, DPMPTSP already has four programmers with decent information technology mastery skills. For the smooth use of this application, DPMPTSP has also provided training to all service apparatus to improve their ability to master appropriate and adequate technology, and the Head of Service Section always supervise the performance and discipline of the apparatus. Supervision is carried out through application monitoring and direct control at the office so that the operation of licensing and non-licensing services will be optimal service to the public.

\section{c. Process Evaluation}

Process evaluation reaches to monitor and check the implementation of predetermined programs. This process evaluation always seeks the management of the programs and strategies that have determined so that it can review the plan and identify important aspects of the program that must keep watch. This evaluation reached to review the situation when the implementation is in progress, find and analyze errors and problems that occur, and as a reference in subsequent policymaking.

In the process of implementing the SIP Sakato and Sakato Sign applications, it has regulated in the Decree of the Governor of West Sumatra Number: 570-498-2017 Concerning Standard Operating Procedures in the Field of Implementation of Licensing and Non-Licensing Services at the Investment Service and One Stop Services of West Sumatra Province and the Decree of the Governor of Sumatra Barat Number: 570 - 500 - 2017 Concerning: Service Standards in the Field of Providing Licensing and Non-Licensing Services at the Investment Service and One Stop Services of West Sumatra Province. Standard Operating Procedures (SOP) and Licensing Service Standards (SPP) are used as an effort to improve the quality of services provided to the community.

In the process of implementing apparatus services in using the application, it is accordance with predetermined standards. Discipline and responsibilities of service providers are also running well, and superiors are always supervising to ensure that work is carried out by following established procedures and standards. However, in the stipulation of the completion time, there are still some delays. In the year 2019, there were $17.49 \%$ of permit applications that did not comply with the stipulated SOP. Delays in completing permits occur due to the lack of requirements uploaded by applicants and delays from the technical office in providing the results of technical studies to DPMPTSP so that the performance of officials in completing the licensing decree is also late. Another thing is the lack of field observers, and this application cannot check the location on maps on the internet that sometimes makes officers slow and even makes it quite hard to find the applicant's area.

The delay in the process of completing this license is still in the natural category. In 2019, there were 3,174 applications for license submitted, 2,619 publishing of licensing completed according to the SOP, and there were 555 permits that were not by following the SOP. It means that as $82.51 \%$ of the issuance of license has been carried out according to the stipulated SOP. It means that as $82.51 \%$ of the publishing of licensing has been carried out according to the stipulated SOP. For more details, the realization of a publishing license can see in the following table : 
Table 1. Realization of the Issuance of the 2019 DPMPTSP Permit

\begin{tabular}{|c|c|c|c|c|c|}
\hline No & $S$ e c t or & Total Overall & $\begin{array}{c}\text { SOP } \\
\text { (Processing } \\
\text { Time) }\end{array}$ & $\begin{array}{c}\text { Amount } \\
\text { According to } \\
\text { SOP }\end{array}$ & $\begin{array}{l}\text { Percentage of } \\
\text { License According to } \\
\text { SOP }\end{array}$ \\
\hline 1 & Capital investment & - & 7 days & 0 & 0.00 \\
\hline 2 & Industry. And trade & 2 & 5 days & 1 & 50.00 \\
\hline 3 & E S D M & 491 & 16 days & 332 & 67.62 \\
\hline 4 & Labor & 42 & 3 days & 22 & 52.38 \\
\hline 5 & Health & 59 & 32 days & 33 & 55.93 \\
\hline 6 & Forestry & 124 & 32 days & 62 & 50.00 \\
\hline 7 & Education & 12 & 62 days & 4 & 33.33 \\
\hline 8 & Marine and Fisheries & 492 & 5 days & 394 & 80.08 \\
\hline 9 & Plantation & 4 & 6 days & 2 & 50.00 \\
\hline 10 & Living environment & 11 & 92 days & 6 & 54.55 \\
\hline 11 & Tourism & - & 6 days & 0 & 0.00 \\
\hline 12 & Transportation & 265 & 14 days & 152 & 57.36 \\
\hline 13 & Ranch & 61 & 4 days & 37 & 60.66 \\
\hline 14 & PU and Spatial Planning & 3 & 17 days & 3 & 100.00 \\
\hline 15 & PSDA & 9 & 5 days & 6 & 66.67 \\
\hline 16 & Social & 37 & 10 days & 21 & 56.76 \\
\hline 17 & Public Housing. Land & - & 30 days & 0 & 0.00 \\
\hline 18 & Cooperatives \& SMEs & - & 10 days & 0 & 0.00 \\
\hline 19 & Kesbangpol & 1.562 & 1 days & 1544 & 98.85 \\
\hline & TOTAL & 3.174 & - & 2.619 & 82.51 \\
\hline
\end{tabular}

The next problem that occurs is the small size of the documented capacity in uploading the applicant's required documents. So that the applicant must compress or reduce the size of the pdf file first before uploading it to the SIP Sakato application. However, for the required documents that are thick and cannot compress, the process of submitting a license application do manually with the applicant who goes directly to the DPMPTSP office of West Sumatra Province. Implementation of the online-based SIP Sakato application is not all done online, there are still several processes that are done manually, such as if the required documents are thick and cannot be uploaded, as some technic agencies still use manual submission of requirements documents.

Based on the above, see that the process of using the SIP Sakato application has experienced several problems. Therefore, the application will be increasing the size of the required document upload capacity and upgrading the application so that it can display the applicant's business location, so that simplify the process of submitting a permit application and streamline the process of completing the community permit applications. Meanwhile, for the implementation of the Sakato Sign application, there were no problems that occurred because it was running well and by following established procedures.

d. Product Evaluation

Product evaluation is reached to measure, and assessing program achievements, by identifying results and benefits, both planned and unplanned, both short and long term. Is done to interpret the worth and profit of the program.

Regarding the response from the licensing service administering apparatus to the use of this application, it is very decent. The SIP Sakato application simplifies and speeds up the process 
of completing a license application starting from registration, checking the validity and correctness of files which are carried out in layers starting from the back office, section heads and heads of fields, process of sending and receiving technical studies by the Technical Service, also the filing process faster and more organized.

The Sakato Sign application accelerates the Head of Office in ratifying and signing application documents for licensing and non-licensing who can finish anytime and wherever even though the Head of Office is on an official trip outside the city.

In early 2020, DPMPTSP surveyed community satisfaction with public services. There is suppose to make people feel satisfied because they think they are obligate appropriately and quickly, the administrative process is easy, simple, and open at low cost, and is served squarely without discrimination. DPMPTSP obtained a score of 83.36 from the results of a community satisfaction survey that follow with 240 respondents consisting of 168 men and 72 women. Based on the Kepmenpan Public Service Assessment guidelines Number KEP / 14 / M.pan / $2 / 2014$, the survey results show that the services provided include in the interval value of 81.26 100.00 with a very decent category. The results of the public satisfaction survey can see more clearly in the following picture:

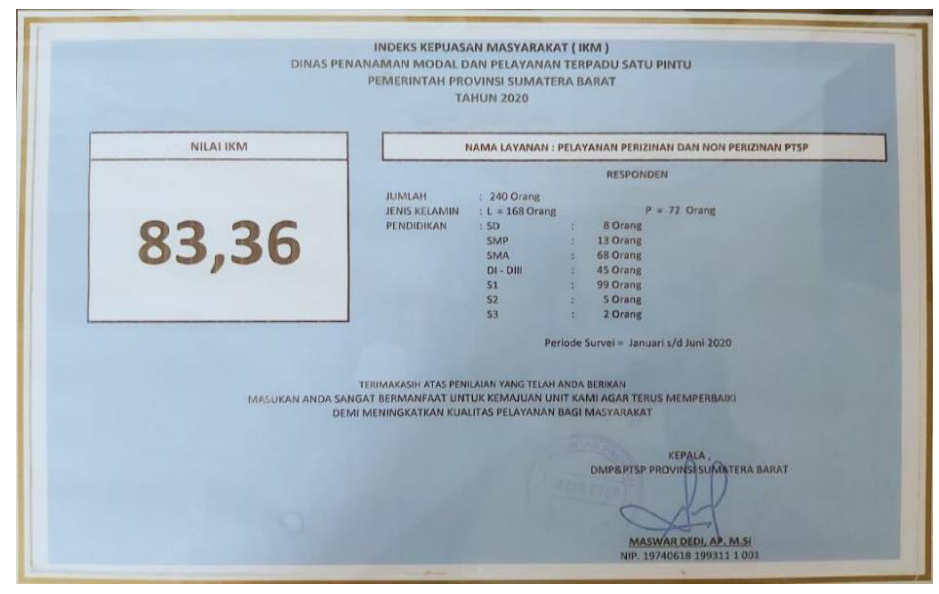

Fig. 1. Public Satisfaction Index Survey Results

The use of the SIP Sakato and Sakato Sign applications in achieving goals such as increasing time and cost efficiency can provide services that are fast, easy, transparent, certainty, simple, and affordable, and professionalism has not fully achieved. In the SIP Sakato application, because there are still several problems that occur as described in the input evaluation and process evaluation sections, So that the implementation of the SIP Sakato application cannot be said to be fully effective.

The use of the Sakato Sign application is decent and has produced satisfying products because it can speed up the service process, make it easier for the Head of Service to validate and sign even though he is outside the office, and can guarantee the correctness and legality of issued documents, and has provided certainty law on document publishing to the public from the Office of Investment and One-Stop Services of West Sumatra Province so that the 
application of the Sakato Sign application in-licensing and non-licensing services at the Investment Service and One-Stop Integrated Service of West Sumatra Province has achieved its goal and can be said to already effective.

\section{Conclusion}

Measurement of effectiveness is reached by analyzing the evaluation of the application of the SIP Sakato and Tanda Sakato Applications at DPMPTSP West Sumatra Province using the CIPP evaluation model developed by Daniel Stufflebeam. CIPP model rests on this view that the most significant goal of program evaluation is not to prove but to improve. Therefore, besides measuring the achievement of the application use objectives, evaluation is also carried out is an orientation towards program improvement. This evaluation does by analyzing four elements, namely Context, Input, Process, and Product. The use of the SIP Sakato application has not yet fully reached the word of effectiveness, but there has been an increase in service that is better than before using the application. It's showed from the results of the evaluation that the public is happier and feels the ease of using this application. however, there are some problems so that it needs to do in the additional budget, application development, increasing internet network speed, adding field survey officers, and providing training and guidebooks. Utilization of the SIP Sakato application to applicants for licensing, so that the services give can achieve effectiveness. Meanwhile, the use of the Sakato Sign application has been running well and is by following predetermined procedures, and can be said to be effective.

\section{References}

[1] A. D. Muryadi, "Model evaluasi program dalam penelitian evaluasi," J. Ilm. Penjas, vol. 3, no. 1, 2017.

[2] Wirawan, Evaluasi:Teori, Model, Metodologi, Standar, Aplikasi dan Profesi. Jakarta: PT Raja Grafindo Persada, 2016.

[3] E. Sutrisno, Budaya Organisasi. Jakarta: Kencana, 2011.

[4] L. J. Moleong, Metodologi Penelitian Kualitatif. Bandung: PT Remaja Rosdakarya, 2012.

[5] I. Mahmudi, “CIPP: Suatu Model Evaluasi Program Pendidikan,” At-Ta'dib, vol. 6, no. 1, p. 122, 2011.

[6] M. R. S. Nurhakim, "Implementasi E-Government Dalam Mewujudkan Transparansi Dan Akuntabilitas Sistem Pemerintahan Modern," J. Ilmu Adm., vol. 11, no. 3, pp. 403-422, 2014. 